\title{
ANALISIS PROBLEMATIKA ZAKAT PADA BAZNAS KOTA TASIKMALAYA: \\ PENDEKATAN METODE ANALYTIC NETWORK PROCESS (ANP)
}

\author{
Oleh: \\ Irman Firmansyah \\ (Dosen Program Studi Akuntansi Univeritas Siliwangi) \\ Wawan Sukmana \\ (Dosen Program Studi Akuntansi Univeritas Siliwangi)
}

\begin{abstract}
Abstrac
Zakat is an obligation that must be carried out by muzakki that not only aims to carry out obligations to Almighty but sharp-edged nature of social justice among mankind. Therefore charity must be managed properly by the board amilin especially by channeling zakat use specifically targeted at Tasikmalaya City Baznas charity board.

The study was to examine the affairs of Baznas perzakatan at Tasikmalaya City. Analysis tool used namely Analysis Network Process (ANP) is a qualitativequantitative method using super decision software. The analysis showed that there is an internal problem which consists of lacking leadership and lacking performance OPZ performance. The problems consist of the absence of external PERDA about channeling zakat institutions and communities less know Baznas. As for an internal solution consisting of leadership and performance maximization of transparency and distribution, while the external solution consisted of socialization and support Baznas scholars. Kendall coefficient ( $W$ ) ranged from 0.970 to 0.9975 means that all respondents have the same relative answer.
\end{abstract}

Keywords: ANP, Koefisien Kendall, Zakat,

\section{Pendahuluan}

Zakat merupakan kewajiban yang dikeluarkan oleh muzaki atau orang yang berkewajiban mengeluarkan zakat. Hal ini dikarenakan dalam harta kita terdapat hak orang lain yang harus dikembalikan kepada yang berhak menerimanya sebagai wujud pensucian harta. Zakat merupakan Ibadah yang mengandung dua dimensi yaitu dimensi hablumminalloh atau hubungan manusia dengan alloh dan dimensi hablumminannas atau hubungan manusia dengan manusia.

Zakat juga berperan penting dalam mewujudkan terciptanya keadilan dalam bidang ekonomi di mana seluruh anggota warga negara mempunyai sumber pendapatan dan income untuk memenuhi kebutuhan sehari-hari dalam rangka menjalankan roda kehidupan dimuka bumi ini. Oleh karena diperlukan lapangan pekerjaan yang cukup sebagai sumber atau ladang pendapatan yang halal. Dengan zakat maka akan terkumpul dana baru (fresh capital) yang bebas dari tekanan- 
tekanan apapun karena memang bersifat sukarela dan merupakan hak para kaum miskin (Amma, 2004).

Menurut Ketua Baznas (Didin) dalam majalah Tempo (12 Juli 2013) mengungkapkan bahwa potensi zakat di Indonesia mencapai angka ratusan triliun rupiah. "Potensi zakat di Indonesia sebesar Rp 217 triliun atau 1,8-4,34 persen dari gross domestic product (GDP). Namun kenyataan zakat yang diterima pada tahun 2012 sebesar Rp2,3 triliun sedangkan pada tahun 2011 sebesar Rp1,73 triliun. Sungguh sangat mengecewakan. Padahal, secara matematis, semestinya minimal yang kita dapatkan adalah sekitar angka Rp 19,3 trilyun per tahun. Dari data di atas, terlihat bahwa potensi zakat yang berhasil digali di Indonesia masih sangat kecil.

Jika mengambil kasus Kota Tasikmalaya, kondisi yang ada tidak jauh berbeda. Menurut data Badan Amil Zakat Nasional (Baznas) Kota Tasikmalaya, pada sepanjang tahun 2011 penerimaan dana zakat hanya Rp. 2 Miliar. Sangat jauh jika dibandingkan dengan potensi yang seharusnya melebihi Rp.10 Miliar (bisnis-jabar.com, Juli 2012). Sumber utama dana yang terkumpul berasal dari zakat profesi PNS pemerintah dan Kemenag. Sedangkan untuk perusahaan, baru sedikit yang menyalurkan melalui Baznas Kota Tasikmalaya.

Oleh karena itu ini merupakan permasalahan yang kiranya penting untuk diteliti, apa yang menyebabkan penerimaan zakat pada Baznas Kota Tasikmalaya sangat kecil jauh dari potensi yang seharusnya diperoleh.

Penelitian ini dimaksudkan untuk mengidentifikasi hal-hal yang menjadi masalah dalam pengelolaan zakat pada Baznas Kota Tasikmalaya, kemudian untuk dapat dipakai sebagai landasan dalam memberikan berbagai alternatif pemecahan dan strategi kebijakan yang tepat untuk mengatasi masalah tersebut.

Tujuannya adalah untuk memberikan masukan-masukan kepada stakeholder terkait seperti organisasi pengelola zakat, ataupun bagi Kementerian Agama sebagai wakil pemerintah yang mengurusi ihwal zakat untuk dapat mengambil policy action yang tepat untuk mengatasi masalah-masalah yang ada, dalam rangka mencapai tujuan yang diinginkan.

Penelitian ini menjadi sangat penting untuk dilakukan agar kita mampu mengidentifikasi hal-hal yang menjadi problem dalam pengelolaan zakat khususnya Baznas Kota Tasikmalaya, kemudian untuk dapat dipakai sebagai landasan dalam memberikan alternatif pemecahan dan strategi kebijakan yang tepat. Sehingga potensi zakat masyarakat Muslim Indonesia yang sangat besar mampu direalisasikan untuk selanjutnya dioptimalkan sebagai instrumen solusi kemiskinan.

\section{Kajian Pustaka}

Zakat merupakan salah satu rukun dalam Islam, sehingga sudah sangat dikenal oleh para kaum muslimin. Zakat dikeluarkan hanya bagi mereka yang telah tercukupi kebutuhan pokoknya. Orang yang membayar zakat dalam Islam disebut muzakki, dan orang yang berhak menerimanya disebut dengan mustahik. Menurut Yusuf Qardhawi (2007), ditinjau dari segi bahasa, dalam Mu'jam Wasith disebutkan bahwa kata zakat merupakan kata dasar (mashdar) dari zaka yang berarti berkah, tumbuh, bersih, dan baik. Sesuatu itu zaka, berarti tumbuh dan berkembang, dan seseorang itu zaka, berarti orang itu baik. 
Secara bahasa (lughat) berarti: tumbuh, berkembang dan berkah (HR. AtTirmidzi) atau dapat pula berarti membersihkan atau mensucikan (QS. At-Taubah: 103). Seorang yang membayar zakat karena keimanannya nicaya akan memperoleh kebaikan yang banyak. Allah SWT berfirman: Artinya : "Pungutlah zakat dari sebagian kekayaan mereka dengan zakat itu kamu membersihkan dan mensucikan mereka....". (QS. At-Taubah: 103). Ayat ini juga mengandung arti lain seperti yang diungkapkan oleh Yusuf Qardhawi (2007) dalam bukunya Hukum Zakat ".... ayat ini juga berarti bahwa arti "tumbuh" dan "Suci" tidak dipakai hanya buat kekayaan, tetapi lebih dari itu, tetapi juga buat jiwa yang menzakatkannya".

Sedangkan menurut terminologi syariah (istilah syara'), zakat berarti sejumlah harta tertentu yang diwajibkan Allah diserahkan kepada orang-orang yang berhak dengan mengeluarkan jumlah tertentu tersebut. Dalam Kamus Besar Bahasa Indonesia disebutkan bahwa zakat adalah jumlah harta tertentu yang wajib dikeluarkan oleh orang Islam dan diberikan kepada golongan yang berhak menerimanya -fakir miskin dan sebagainya menurut yang telah ditetapkan oleh syara (Departemen Pendidikan dan Kebudayaan, 1999).

Yusuf Qardhawi (2007) menjelaskan bahwa kata zakat dalam bentuk ma'rifah (definisi) disebut 30 kali di dalam Al-Qur'an. Semuanya disebutkan bersamaan dengan penyebutan sholat dan hanya satu kali yang tidak bersamaan dengan kata shalat, namun masih dalam konteks yang sama, yaitu firman-Nya; Artinya : "Dan orang-orang yang giat menunaikan zakat", setelah ayat: "orangorang yang khusu' dalam bershalat". (QS. Al-Mu'minun: 2 dan 4).

Di samping sebagai kewajiban agama, zakat juga merupakan bentuk ibadah yang memiliki dua dimensi sekaligus. Yaitu vertikal (bentuk ketaatan kepada Allah) dan horizontal (sebagai income transfer bagi kaum dhu'afa). Dalam perekonomian Islam, zakat merupakan ciri yang tidak terdapat pada sistem ekonomi lainnya, karena zakat merupakan aturan yang berasal dari Al-Qur'an dan telah ditetapkan kepada siapa harus didistribusikan. Dalam ekonomi Islam, zakat merupakan implementasi dari sisi azas keadilan.

Menurut Rachmawati (2004), zakat memiliki beberapa karakteristik yang membedakannya dari jenis pungutan lain, yaitu: (1) zakat merupakan kewajiban religius yang dikenakan pada individual maupun korporasi atau perusahaan. Zakah rate telah ditentukan pada flat basis. Berkaitan dengan hal ini zakat tidak dapat digunakan sebagai alat politik layaknya pajak di negara-negara maju; (2) pengumpulan zakat tidak begitu saja diserahkan pada individu, pemerintah bertanggungjawab atas pengumpulannya. Sehingga zakat bukanlah sedekah (charity), dan harus dikelola dengan terorganisir; (3) Zakat dikenakan secara luas terhadap seluruh aktivitas usaha mulai dari peternakan, pertanian, aktivitas komersial, pertambangan, hingga aset tidak bergerak. Zakah rate bagi setiap unit usaha berbeda sesuai dengan tingkat kesulitan dalam proses produksi. Contohnya, $5 \%$ untuk produk pertanian dengan sistem irigasi dan 10\% untuk tadah hujan; $5 \%$ untuk madu dari lebah bukit dan $10 \%$ untuk lebah peternakan. Termasuk perbedaan bagi aset diam dan aset yang dipakai usaha, sehingga dalam ekspektasi rasional memberi motif agar tidak melakukan penimbunan; (4) Penerima zakat (mustahik) telah ditentukan dalam Al-Quran, yang berupa delapan golongan. Ini menegaskan fungsi utama zakat adalah sebagai alat pengentasan kemiskinan, dan merupakan alasan rasional bahwa zakat tidak dapat digunakan sebagai sumber 
pendapatan pemerintah untuk membiayai pengeluaran Negara; (5) Zakat dikenakan pada individu yang telah terkena nishab (batas) atau minimum wealth. Individu yang berada di atas limit tersebut wajib membayar zakat sedangkan yang berada di bawah limit tidak terkena kewajiban bahkan mereka menjadi penerima (mustakhik) zakat. Ini merupakan konsep awal minimum exemption limit dari pemikiran fiskal modern yang kemudian dikenal dengan nama negative income taxes.

Berikut ini dijelaskan beberapa hal mendasar tentang manajemen organisasi pengelola zakat. Kemudian kita sebut dengan prinsip-prinsip dasar manajemen organisasi pengelola zakat (OPZ) yang mencakup tiga aspek yakni: (a) aspek kelembagaan, (b) aspek sumber daya manusia, dan (c) aspek sistem pengelolaan.

a. Aspek Kelembagaan

Dari aspek kelembagaan, sebuah OPZ seharusnya memperhatikan berbagai faktor berikut: (a) Visi dan misi yang jelas. Hanya dengan visi dan misi inilah maka aktivitas/kegiatan akan terarah dengan baik. Jangan sampai program yang dibuat cenderung 'sekedar bagi-bagi uang'. Apalagi tanpa disadari dibuat program 'pelestarian kemiskinan', (b) Kedudukan dan Sifat Lembaga yang independen, netral, tidak berpolitik dan tidak diskriminasi. Artinya, lembaga ini tidak mempunyai ketergantungan kepada orang-orang tertentu atau lembaga lain. Lembaga yang demikian akan lebih leluasa untuk memberikan pertanggungjawaban kepada masyarakat donatur, dan (c) Legalitas dan Struktur Organisasi. Khususnya untuk LAZ, badan hukum yang dianjurkan adalah Yayasan yang terdaftar pada akta notaris dan pengadilan negeri. Struktur organisasi seramping mungkin dan disesuaikan dengan kebutuhan, sehingga organisasi akan lincah dan efisien.

b. Aspek Sumber Daya Manusia (SDM)

SDM merupakan asset yang paling berharga. Sehingga pemilihan siapa yang akan menjadi amil zakat harus dilakukan dengan hati-hati. Untuk itu perlu diperhatikan hal-hal sebagai berikut:

(1) Merubah Paradigma Amil Zakat

Begitu mendengar pengelolaan zakat, sering yang tergambar dalam benak kita adalah pengelolaan yang tradisional, dikerjakan dengan waktu sisa, SDM-nya paruh waktu, pengelolanya tidak boleh digaji, dan seterusnya. Sudah saatnya kita merubah paradigma dan cara berpikir kita. Amil zakat adalah sebuah profesi. Konsekuensinya dia harus professional. Untuk professional, salah satunya harus bekerja purna waktu (full time). Untuk itu harus digaji secara layak, sehingga dia bisa mencurahkan segala potensinya untuk mengelola dana zakat secara baik. Jangan sampai si amil zakat masih harus mencari tambahan penghasilan, yang pada akhirnya dapat mengganggu pekerjaannya selaku amil zakat.

(2) Kualifikasi SDM

Jika kita mengacu di jaman Rasulullah SAW, yang dipilih dan diangkat sebagai amil zakat merupakan orang-orang pilihan. Orang yang memiliki kualifikasi tertentu. Secara umum kualifikasi yang harus dimiliki oleh amil zakat adalah: muslim, amanah, dan paham fikih zakat.

c. Sistem Pengelolaan 
OPZ harus memiliki sistem pengelolaan yang baik. Unsur-unsur yang harus diperhatikan adalah: (a) Memiliki sistem, prosedur dan aturan yang jelas, (b) Manajemen terbuka, (c) Mempunyai rencana kerja (activity plan), (d) Memiliki 9 Komite Penyaluran (lending committee), (e) Memiliki sistem akuntansi dan manajemen keuangan, (f) Bersedia diaudit, (g) Menjunjung transparansi, dan (h) Senantiasa melakukan perbaikan terus-menerus (continous improvement).

Terdapat beberapa masalah yang berhasil diinventarisir dari riset-riset sebelumnya dalam hal pengelolaan zakat di Indonesia sehingga berimplikasi tidak maksimalnya proses pengelolaan, pengumpulan hingga penyaluran zakat. Sudewo (2004) umpamanya memaparkan hal-hal yang secara umum menjadi problem dalam pengumpulan zakat yang maksimal yakni: regulasi dan political wiil yang kurang mendukung, ketidakpercayaan para muzakki terhadap lembaga pengelola zakat yang ada baik swasta maupun terutama pemerintah, hingga masalah internal organisasi pengelola zakat sendiri, seperti kurang akuntabel, lack of transparency, dan masalah manajerial.

\section{Metode Penelitian}

Dalam metodologi Analytic Network Process (ANP), data yang digunakan merupakan data primer yang didapat dari hasil wawancara (indepth interview) dengan pakar, praktisi, dan regulator, yang memiliki pemahaman tentang permasalahan yang dibahas. Dilanjutkan dengan pengisian kuesioner pada pertemuan kedua dengan responden. Data siap olah dalam ANP adalah variabelvariabel penilaian responden terhadap masalah yang menjadi objek penelitian dalam skala numerik (Jarkasih, 2008).

Pemilihan responden pada penelitian ini dilakukan secara purposive sample (sengaja) dengan mempertimbangkan pemahaman responden tersebut terhadap permasalahan dalam pengelolaan zakat di Indonesia khususnya di Tasikmalaya. Jumlah responden dalam penelitian ini terdiri dari lima orang, dengan pertimbangan bahwa mereka cukup berkompeten dalam mewakili keseluruhan populasi. Dalam analisis ANP jumlah sampel/responden tidak digunakan sebagai patokan validitas. Syarat responden yang valid dalam ANP adalah bahwa mereka adalah orang-orang yang ahli di bidangnya. Oleh karena itu, responden yang dipilih dalam survei ini adalah para pakar/peneliti ekonomi Islam dan para praktisi/profesional yang berkecimpung dalam masalah pengelolaan zakat.

Pertanyaan dalam kuesioner ANP berupa pairwise comparison (pembandingan pasangan) antar elemen dalam cluster untuk mengetahui mana di antara keduanya yang lebih besar pengaruhnya (lebih dominan) dan seberapa besar perbedaannya dilihat dari satu sisi. Skala numerik 1-9 yang digunakan merupakan terjemahan dari penilaian verbal.

Pengisian kuesioner oleh responden harus didampingi peneliti untuk manjaga konsistensi dari jawaban yang diberikan. Pada umumnya, pertanyaan pada kuesioner ANP sangat banyak jumlahnya. Sehingga faktor-faktor non teknis dapat menyebabkan tingginya tingkat inkonsistensi.

Tabel 1: Perbandingan Skala Verbal dan Skala Numerik \begin{tabular}{l|l} 
SKALA VERBAL & SKALA NUMERIK
\end{tabular} 


\begin{tabular}{|c|c|}
\hline Amat sangat lebih besar pengaruhnya & 9 \\
\hline & 8 \\
\hline Sangat lebih besar pengaruhnya & 7 \\
\hline & 6 \\
\hline Lebih besar pengaruhnya & 5 \\
\hline Sedikit lebih besar pengaruhnya & 4 \\
\hline & 3 \\
\hline Sama besar pengaruhnya & 2 \\
\hline
\end{tabular}

Sumber: Ascarya (2005)

Data yang didapatkan dari penelitian akan dianalisa dengan metode ANP yang merupakan metode yang dapat digunakan dalam berbagai studi kualitatif yang beragam, seperti pengambilan keputusan, forecasting, evaluasi, mapping, strategizing, alokasi sumber daya, dan lain sebagainya. Metodologi ANP memiliki tiga fungsi utama sebagai berikut:

a. Melakukan strukturisasi pada kompleksitas

Dalam penelitiannya, Saaty (2006) menemukan adanya pola-pola yang sama dalam sejumlah contoh tentang bagaimana manusia memecahkan sebuah kompleksitas dari masa ke masa. Dimana kompleksitas distruktur secara hierarkis ke dalam cluster-cluster yang homogen dari faktor-faktor.

b. Pengukuran ke dalam skala rasio

Metodologi pengambilan keputusan yang terdahulu pada umumnya menggunakan pengukuran level rendah (pengukuran ordinal atau interval), sedangkan metodologi ANP menggunakan pengukuran skala rasio yang diyakini paling akurat dalam mengukur faktor-faktor yang membentuk hierarki. Level pengukuran dari terendah ke tertinggi adalah nominal, ordinal, interval, dan rasio. Setiap level pengukuran memiliki semua arti yang dimiliki level yang lebih rendah dengan tambahan arti yang baru. Pengukuran interval tidak memiliki arti rasio, namun memiliki arti interval, ordinal, dan nominal. Pengukuran rasio diperlukan untuk mencerminkan proporsi. Untuk menjaga kesederhanaan metodologi, Saaty (2006) mengusulkan penggunaan penilaian rasio dari setiap pasang faktor dalam hierarki untuk mendapatkan (tidak secara langsung memberikan nilai) pengukuran skala rasio. Setiap metodologi dengan struktur hieraki harus menggunakan prioritas skala rasio untuk elemen di atas level terendah dari hierarki. Hal ini penting karena prioritas (atau bobot) dari elemen di level manapun dari hierarki ditentukan dengan mengalikan prioritas dari elemen pada level dengan prioritas dari elemen induknya. Karena hasil perkalian dari dua pengukuran level interval secara matematis tidak memiliki arti, skala rasio diperlukan untuk perkalian ini. ANP menggunakan skala rasio pada semua level terendah dari hierarki/jaringan, termasuk level terendah (alternatif dalam model pilihan). Skala rasio ini menjadi semakin penting jika prioritas tidak hanya digunakan untuk aplikasi pilihan, namun untuk aplikasiaplikasi lain, seperti untuk aplikasi alokasi sumber daya.

c. Sintesis

Sintesis merupakan kebalikan dari analisis. Kalau analisis berarti mengurai entitas material atau abstrak ke dalam elemen-elemennya, maka sintesis berarti menyatukan semua bagian menjadi satu kesatuan. Karena kompleksitas, situasi 
keputusan penting, atau prakiraan, atau alokasi sumber daya, sering melibatkan terlalu banyak dimensi bagi manusia untuk dapat melakukan sintesis secara intuitif, kita memerlukan suatu cara untuk melakukan sintesis dari banyak dimensi. Meskipun ANP memfasilitasi analisis, fungsi yang lebih penting lagi dalam ANP adalah kemampuannya untuk membantu kita dalam melakukan pengukuran dan sintesis sejumlah faktor-faktor dalam hierarki atau jaringan.

\section{Hasil dan Pembahasan}

Atas hasil penelitian yang telah dilakukan maka diketahui terdapat beberapa masalah yang ada pada BAZNAS Kota Tasikmalaya yang penulis bagi menjadi dua kategori yaitu masalah internal dan masalah eksternal. Berikut adalah masalah yang terjadi yang menimbulkan problematika zakat pada Baznas Kota Tasikmalaya:

1. Masalah Internal

Di antara masalah internal yang ada yaitu: 1) masih kurangnya profesionalisme para pegawai Baznas. Hal ini dikarenakan tidak adanya pelatihan khusus yang dilakukan oleh para pegawai, pelatihan hanya dilakukan sesekali sehingga pekerjaan yang dilakukan oleh pegawai mengandalkan kreativitas sendiri, berfikir dan berjalan tanpa adanya suatu standar pekerjaan sebagai seorang amilin (SOP); 2) masalah pendistribusian zakat yang dirasa sulit untuk tepat sasaran ditambah dengan transparansi ke masyarakat yang masih kurang sehingga masyarakat masih menganggap Baznas adalah organisasi yang jauh dari keinginan masyarakat terutama muzakki; 3) minimnya kinerja OPZ yang tentunya belum dapat membantu baik penerimaan maupun penyaluran zakat; 4) masih kurangnya tunjangan para pegawai maupun struktural, bahkan biaya operasional untuk melakukan tugas. Tunjangan pegawai seharusnya ikut diprioritaskan karena akan memacu pekerjaan; dan 5) peran serta pimpinan yang masih belum maksimal dalam menjalankan operasional Baznas. Hal ini membuat pegawai lambat bergerak (aksi) karena menunggu keputusan pimpinan.

2. Masalah Eksternal

Beberapa masalah ekternal yaitu: 1) kepercayaan masyarakat (muzakki) terhadap Baznas Kota Tasikmalaya masih kurang. Sehingga muzakki lebih memilih untuk menyalurkan zakatnya langsung oleh diri sendiri; 2) masih kurangnya peran serta ulama dalam memberikan dukungan kepada muzakki untuk menyalurkan zakatnya ke lembaga terutama ke Baznas Kota Tasikmalaya; 3) secara keseluruhan mayoritas masyarakat masih belum mengenal Baznas secara lebih dekat sehingga belum mengetahui peran sertanya dalam membantu menyalurkan zakat; 4) belum adanya Perda yang mengatur bahwa zakat harus disalurkan melalui lembaga khusunya Baznas Kota Tasikmalaya; dan 5) kesadaran masyarakat masih kurang dalam mengeluarkan zakatnya.

Dari permasalahan di atas, maka penulis pun menawarkan solusi yang terbaik untuk mengatasi problematika zakat yang ada pada BAZNAZ Kota Tasikmalaya atas hasil indepth interview para pakar di Kota Tasikmalaya. Solusi yang ditawarkan dibagi menjadi dua kategori yaitu solusi internal dan solusi eksternal. Berikut adalah solusi yang ditawarkan:

1. Solusi Internal 
Terdapat lima solusi internal yaitu: 1) mengadakan pelatihan pengurus terutama teknis pekerjaan yang sesuai dengan SOP yang seharusnya; 2) meningkatkan kualitas distribusi guna meningkatkan kepercayaan masyarakat terhadap lembaga Baznas serta transparansi dalam melaporkan hasil penyaluran kepada mustahik; 3) memaksimalkan kinerja organisasi perangkat zakat (OPZ) yang selama ini terkesan kurang berperan maksimal dalam membantu Baznas; 4) memberi tambahan tunjangan yang sesuai dengan tingkat pekerjaan disertai dengan target pekerjaan yang ditetapkan oleh manajemen Baznas agar memiliki tanggungjawab atas pekerjaannya; dan 5) meningkatkan kinerja pimpinan guna memaksimalkan kinerja organisasi lembaga Baznas.

2. Solusi Eksternal

Ada tiga solusi eksternal yaitu: 1) melakukan sosialisasi kepada masyarakat mengenai keberadaan Baznas Kota Tasikmalaya sehingga masyarakat mengetahui keberadaan dan fungsi lembaga pengelola (penyalur) zakat ini; 2) dibutuhkan dukungan/peran serta ulama dalam memberikan arahan mengenai penyaluran zakat melalui lembaga yang telah ditetapkan oleh pemerintah agar tepat sasaran; dan 3) harus ada Perda yang mengatur penyaluran zakat melalui lembaga Baznas Kota Tasikmalaya.

Berdasarkan permasalahan dan solusi yang ditawarkan di atas, maka dibentuklan jaringan (Model) ANP guna menganalisis hasil penelitian sehingga dibentuk kuesioner sesuai masalah dan solusi yang telah dijelaskan sebelumnya. Berikut adalah model penelitiannya:

\section{ANALISIS PROBLEMATIKA ZAKAT PADA BAZNAS KOTA TASIKMALAYA}




\section{Gambar 1: Jaringan ANP}

Atas hasil analisis menggunakan software super decision berdasarkan konsensus dari para responden yaitu pakar zakat dan orang yang paling mengetahui kondisi Baznas Kota Tasikmalaya baik dari kalangan akademisi, pemerintah maupun pengurus, maka diketahui masalah yang paling besar di internal lembaga yaitu minimnya kinerja pimpinan. Pimpinan lembaga saat ini kurang berperan aktif dan power full dalam menjalankan roda operasi lembaga sehingga segala kebijakan menjadi lambat untuk dikerjakan. Sedangkan masalah yang kedua yaitu minimnya kinerja OPZ, terkesan OPZ tidak bekerja karena tidak ada rangsangan dari yang memberi tugas terutama rangsangan sisi finansial, serta yang ketiga yaitu masalah distribusi dan transparansi. Masalah ini menjadi sorotan muzakki karena kepercayaan pengelolaan zakat terhadap lembaga adalah apakah zakat disampaikan kepada pihak yang benar-benar tepat sasaran, serta bagaimana laporan tanggungjawab atas kegiatannya kepada muzakki. 
Nilai rater agreement yaitu sebesar $\mathrm{W}=0,99$ atau $99 \%$ yang menunjukkan kesepakatan yang tinggi di antara responden dalam menjawab masalah. Untuk lebih jelasnya dapat dilihat pada tabel 2 .

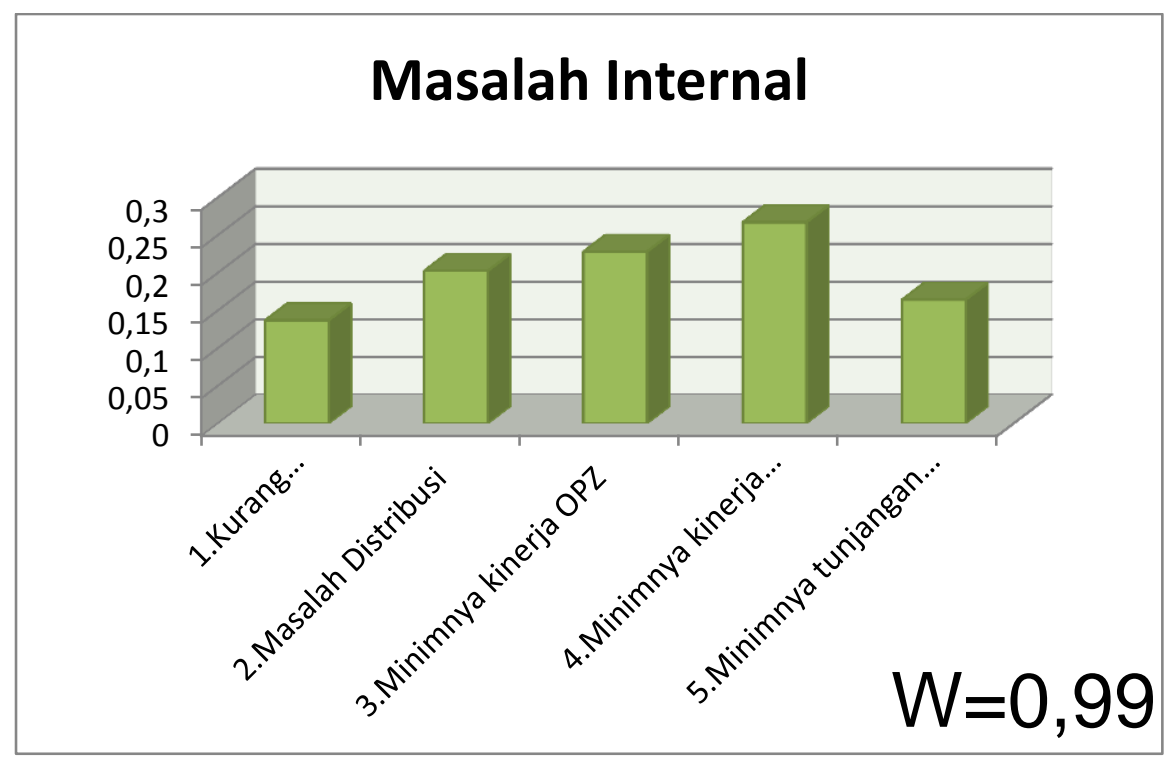

Gambar 2: Prioritas Masalah Internal

Prioritas selanjutnya yaitu dari sisi masalah eksternal lembaga. Tabel 3 menunjukkan priositas masalah eksternal dan terlihat ada 3 masalah yang pengaruhnya hampir sama. Namun dari masalah tersebut, bahwa masalah utama dari sisi eksternal yaitu tidak adanya Perda yang mengatur penyaluran zakat melalui lembaga Baznas Kota Tasikmalaya, dan masalah yang kedua yaitu masyarakat yang kurang mengenal Baznas dalam artian keberadaan dan fungsi Baznas masih belum diketahui oleh banyak orang khususnya muzakki. Adapun nilai rater agreement aspek masalah eksternal yaitu sebesar $\mathrm{W}=0,989$ atau 98,9\%. Nilai ini hampir sama dengan aspek masalah internal yang menunjukkan kesamaan jawaban di antara masing-masing responden.

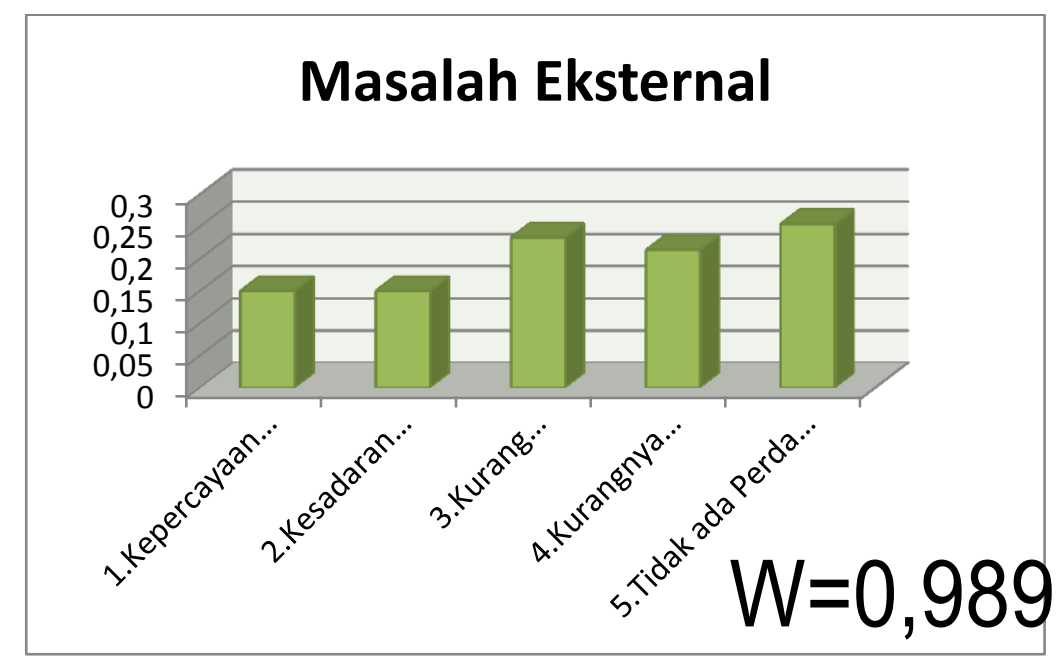

401 | Jurnal Riset Akuntansi dan Keuangan Vol.2 | No.2 | 2014 


\section{Gambar 3: Prioritas Masalah Eksternal}

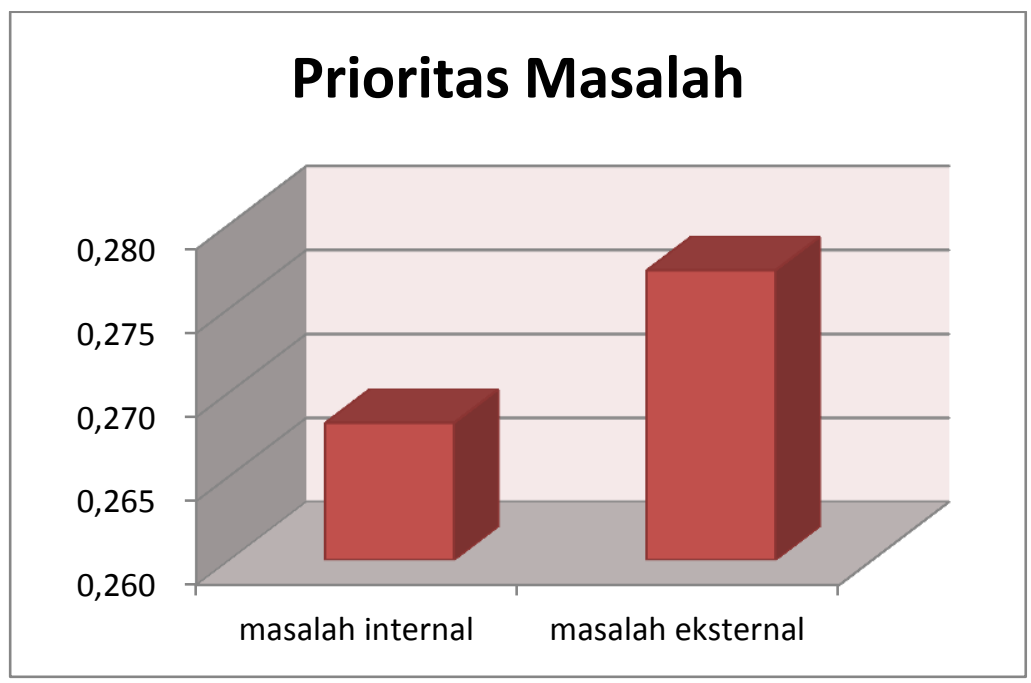

Gambar 4: Prioritas Masalah

Dari kedua aspek masalah yang telah dijelaskan di atas, maka dapat kita lihat pada gambar 4 menunjukkan bahwa aspek masalah eksternal ternyata lebih besar pengaruhnya terhadap problem zakat pada Baznas Kota Tasikmalaya mengingat pihak eksternal terdiri dari muzakki yang akan menyalurkan zakatnya ke lembaga. Namun demikian masalah eksternal belum tentu dapat diatasi dengan solusi eksternal pula hal ini karena pihak pengelola lembaga lah yang sangat berperan aktif dalam mengelola lembaga itu sendiri guna memberikan kepercayaan kepada masayarakat.

Untuk melihat pengaruh tertinggi dalam cluster masalah secara keseluruhan, maka dapat dilihat pada gambar 5.

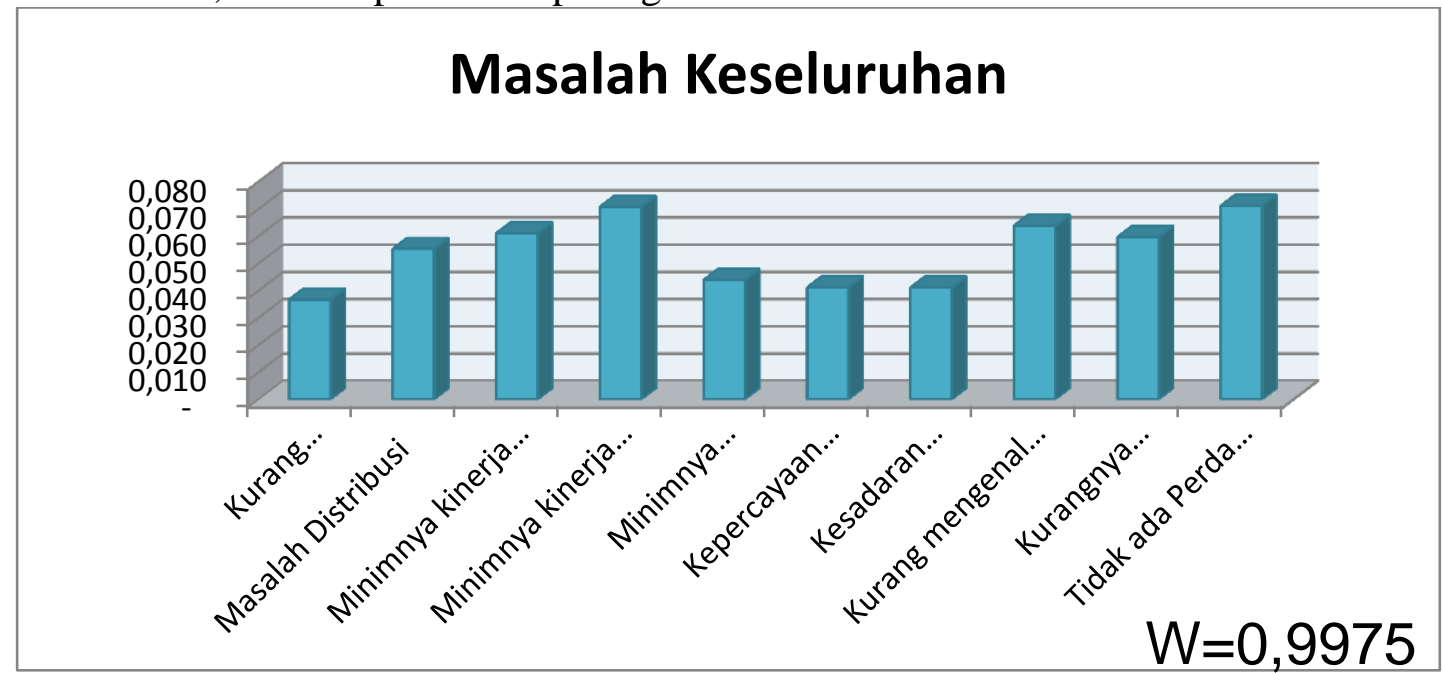

\section{Gambar 5: Prioritas Masalah Keseluruhan}

Dari gambar di atas dapat kita lihat ternyata minimnya kinerja pimpinan serta tidak adanya Perda tentang bayar zakat ke lembaga menjadi masalah utama 
yang sama pengaruhnya terhadap problem zakat pada lembaga Baznas Kota Tasikmalaya saat ini. Nilai rater agreement sebesar $\mathrm{W}=0,9975$ menunjukkan semua jawaban dari responden sangat homogen.

Setelah diketahui masalah yang ada, maka langkah selanjutnya yaitu membuat solusi untuk menyelesaikan masalah yang terjadi. Aspek solusi dibagi menjadi dua yaitu solusi internal dan solusi eksternal.

Hasil kuesioner responden yang dianalisis menggunakan software super decision dapat dilihat pada gambar 6.

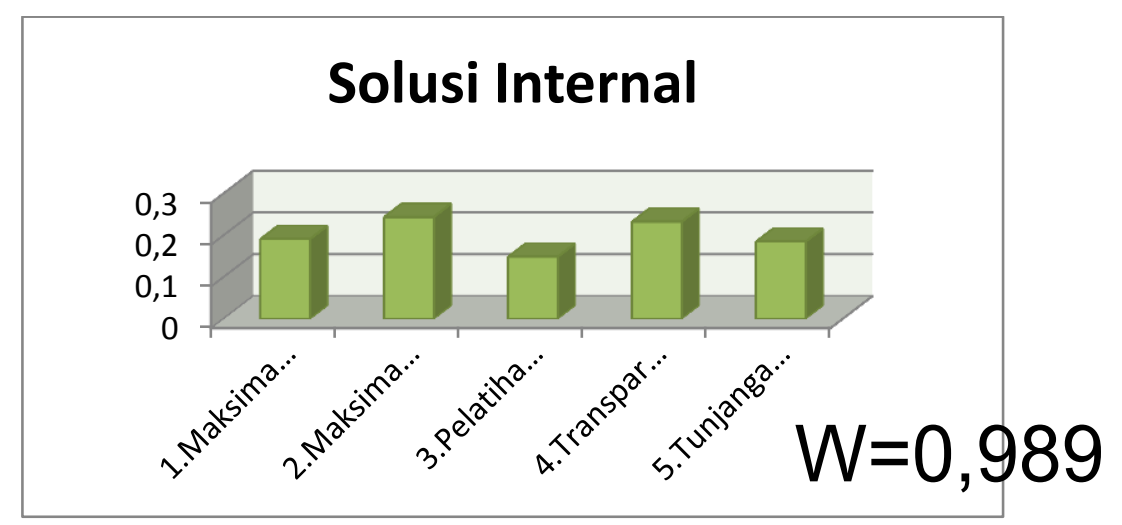

Gambar 6. Prioritas Solusi Internal

Berdasarkan gambar 6 di atas, ada dua solusi internal yang paling tinggi yaitu maksimalisasi kinerja pimpinan, hal ini menunjukkan bahwa jika pimpinan dapat lebih fokus terhadap pekerjaannya maka masalah internal cenderung dapat teratasi mengingat saat ini para pekerja (staf) cenderung menunggu keputusan atau kebijakan pimpinan dalam melakukan aksi. Sedangkan solusi yang kedua yaitu masalah transparansi dan distribusi. Masalah transparansi yang sudah dilakukan mungkin belum maksimal dapat diterima oleh masyarakat sehingga Baznas harus lebih meningkatkan lagi transparansi laporan keuangan dan distribusi yang diketahui oleh masyarakat agar masyarakat lebih mempercayai penyaluran zakat melalui lembaga. Nilai rater agreement prioritas aspek solusi internal sebesar $\mathrm{W}=0,989$ sehingga koefisien yang sangat besar ini menunjukkan kesamaan jawaban dari tiap responden.

Selanjutnya priositas aspek solusi eksternal yang ditunjukkan pada gambar 7. Dari tiga solusi yang ditawarkan, ternyata solusi yang paling tinggi yaitu harus meningkatkan lagi sosialisasi Baznas ke masyarakat. Ini membuktikan bahwa sosialisasi yang telah dilakukan saat ini cendeung masih sangat kurang karena sosialisasi hanya melalui media cetak tidak menunjukkan kedekatan dengan para muzakki, sehingga dapat dilakukan salah satunya dengan pendekatan ke masyarakat. Kemudian solusi kedua yaitu dukungan ulama kepada masyarakat mengenai pentingnya penyaluran zakat melalui lembaga khususnya Baznas yang merupakan lembaga di bawah pemerintah. Kepentingan tersebut dikarenakan zakat yang dikeluarkan oleh muzakki harus tepat sasaran guna kemajuan bersama. Nilai rater agreement aspek solusi eksternal sebesar $\mathrm{W}=0,97$. Sehingga koefisien yang sangat besar ini menunjukkan kesepakatan di antara responden. 


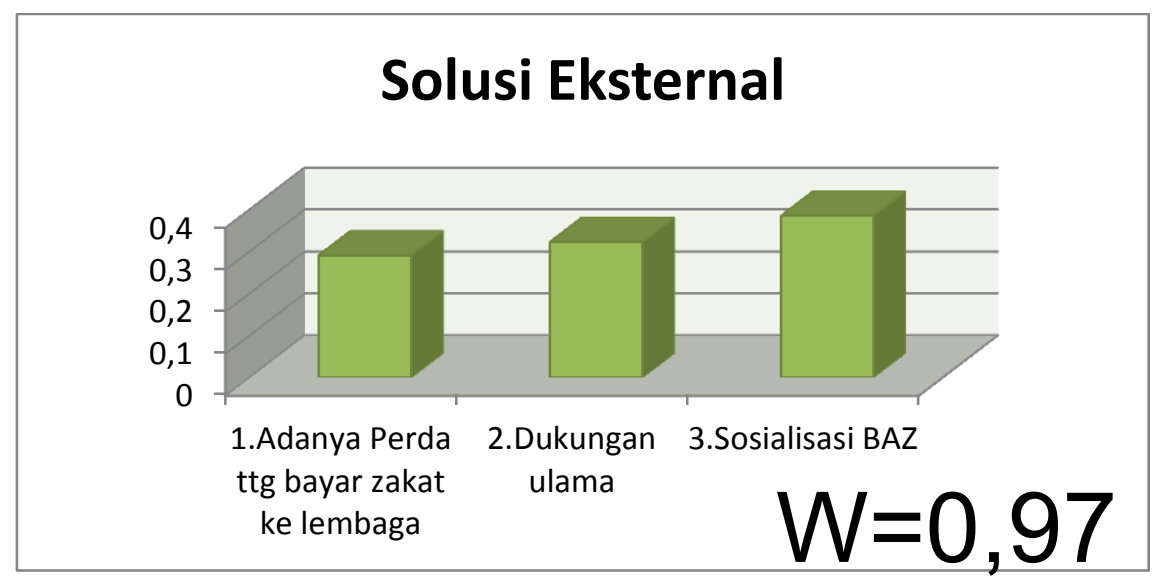

Gambar 7. Prioritas Solusi Eksternal

Dari solusi-solusi yang ditawarkan di atas yang terdiri dari solusi internal dan solusi eksternal maka hasil analisis menunjukkan bahwa prioritas solusi internal menunjukkan solusi yang paling tinggi atau paling utama pengaruhnya dalam menyelesaikan masalah yang ada di Baznas Kota Tasikmalaya baru diikuti dengan solusi eksternal. Hasil dapat dilihat pada gambar 8 bahwa solusi internal menunjukkan grafik lebih tinggi. Ini menunjukkan bahwa penyelesaian atas masalah internal harus didahulukan mengingat pengelolaan lembaga yang baik akan menunjukkan nilai yang baik pula dari pandangan masyarakat khususnya muzakki.

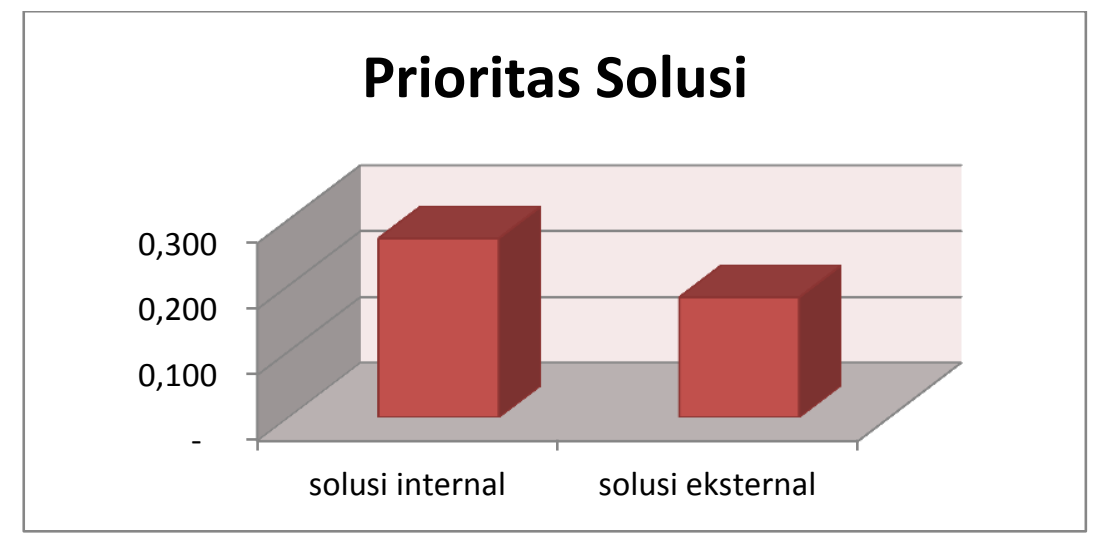

Gambar 8. Prioritas Solusi

Untuk mengetahui solusi yang paling tinggi di antara semua solusi baik internal maupun eksternal dapat dilihat pada gambar 9. Hasil analisis menunjukkan bahwa dari keseluruhan solusi yang ada, sosialisasi Baznas adalah solusi yang paling tinggi pengaruhnya terhadap problem Baznas Kota Tasikmalaya yang selanjutnya diikuti dengan maksimalisasi kinerja pimpinan dan transparansi dan distribusi. Koefisien Kendal sebesar W=0,996 sehingga menunjukan kesamaan/kesepakatan jawaban di antara para responden. Adapun hasil analisis dapat dilihat pada gambar 9. 


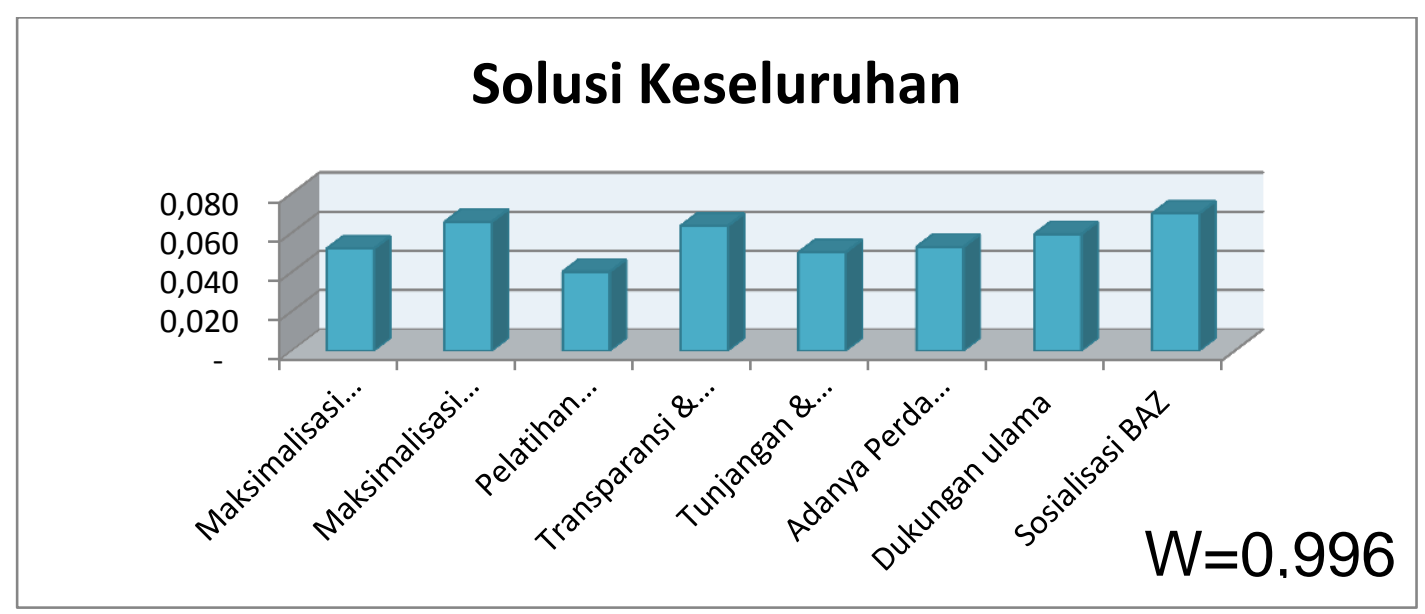

Gambar 9. Prioritas Solusi Keseluruhan

\section{Simpulan}

Berdasarkan hasil analisis diketahui bahwa masalah penyebab terjadinya problematika zakat pada Baznas Kota Tasikmalaya dibagi dua yaitu masalah internal dan masalah eksternal. Masalah tertinggi pada cluster internal yaitu minimnya kinerja pimpinan yang diikuti dengan minimnya kinerja OPZ. Sedangkan masalah eksternal tertinggi yaitu tidak adanya Perda mengenai penyaluran zakat ke lembaga yang diikuti dengan kurang mengenalnya masyarakat terhadap Baznas.

Sedangkan solusi untuk menyelesaikan problematika zakat pada Baznas Kota Tasikmalaya terdiri dari solusi internal dan solusi eksternal. Adapun solusi internal yang paling berpengaruh yaitu maksimalisasi kinerja pimpinan dilanjutkan dengan transparansi dan distribusi. Sedangkan solusi eksternal terdiri dari sosialisasi Baznas dan dukungan ulama. Koefisien kendal antara para responden sekitar 0,970 - 0,9975 yaitu nilai yang menandakan kesamaan di antara jawaban para responden.

\section{Saran}

Terdapat beberapa saran yang penulis sampaikan di antaranya:

1. Atas hasil penelitian ini, diharapkan menjadi bahan pengambilan kebijakan pengembangan zakat khususnya di Kota Tasikmalaya, baik bagi pemerintah sebagai pemilik regulasi di Indonesia maupun bagi pihak lembaga dan pihak lainnya

2. Pengembangan penelitian dapat dilakukan pada lingkup objek yang lebih luas bukan pada objek lembaga zakat daerah guna menjeneralisir hasil penelitian

\section{Daftar Pustaka}

Abidin, Hamid (Ed), 2004, Reinterpretasi Pendayagunaan ZIS, Menuju Efektivitas Pemanfaatan Zakat Infak Sedekah, Jakarta: Piramedia.

Amma, Faris, dkk, 2004, "Zakat Pilar Islamisasi Ekonomi di Indonesia", Makalah.

Ascarya, 2005, Analytic Network Process (ANP): Pendekatan Baru Studi Kualitatif, Pusat Pendidikan dan Studi Kebanksentralan, Bank Indonesia.

Dalimunthe, Ritha F., 2007, "Sejarah Perkembangan Ilmu Manajemen”, Makalah. 
Departemen Pendidikan dan Kebudayaan (1999), Kamus Besar Bahasa Indonesia, Balai Pustaka: Jakarta

Hafidhuddin, Didin, 2006, "Zakat sebagai Tiang Utama Ekonomi Syariah", Makalah pada Seminar Bulanan Masyarakat Ekonomi Syariah (MES), Jakarta, Aula Bank Mandiri Tower, 20 Nopember 2006.

Jarkasih, Muhamad, 2008, "Analisis Masalah dalam Pengembangan Sukuk Korporasi di Indonesia dengan Metode Analytic Network Process (ANP)", Skripsi pada Sekolah Tinggi Ekonomi Islam (STEI) Tazkia, tidak diterbitkan.

Prianita, Anita, 2005, "Peran Lembaga Zakat dalam Pemberdayaan Ekonomi Umat", Makalah pada Lomba Karya Tulis Ekonomi Islam (LKTEI), Temilnas IV FoSSEI 2005, Mataram.

Rachmawati, Erna (2004), Analisis Fiskal dan Performa Zakat di Indonesia. Paper

Saaty, Thomas L. dan Vargas, L.G. 2006. Decision Making with the Analytic Network Process. Springer. USA

Sudewo, Eri, 2004, Manajemen Zakat: Tinggalkan 15 Tradisi Terapkan 4 Prinsip Dasar, Jakarta: Spora Internusa Prima.

Suharto, Edi, 2008, "Islam dan Negara Kesejahteraan", Makalah pada Perkaderan Darul Arqam Paripurna (DAP) Ikatan Mahasiswa Muhammadiyah (IMM), Jakarta 18 Januari 2008.

Yusuf Qardhawi. 2007. Hukum Zakat. Pustaka Litera Antar Nusa. Jakarta 